\title{
MX2 wt Allele
}

National Cancer Institute

\section{Source}

National Cancer Institute. MX2 wt Allele. NCI Thesaurus. Code C101553.

Human MX2 wild-type allele is located in the vicinity of $21 \mathrm{q} 22.3$ and is approximately 46 $\mathrm{kb}$ in length. This allele, which encodes interferon-induced GT P-binding protein Mx2, is involved in both binding and hydrolysis of GTP. 